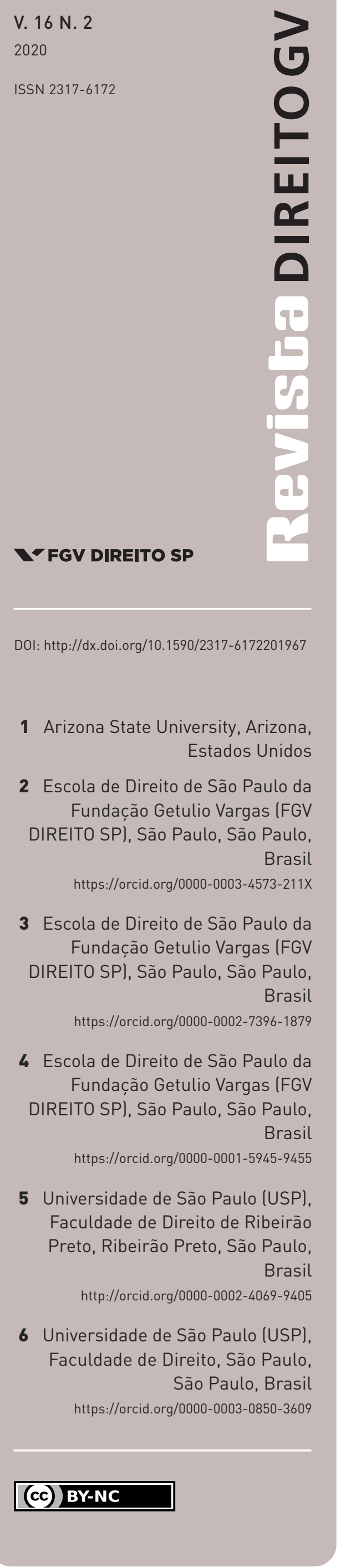

\title{
Access to justice and inequalities: an interview with Professor Rebecca Sandefur
}

ACESSO À JUSTIÇA E DESIGUALDADES: UMA ENTREVISTA COM A PROFESSORA REBECCA SANDEFUR

Interviewee:

Rebecca Sandefur ${ }^{1}$

Interviewers:

Daniela Monteiro Gabbay², Luciana Gross Cunha ${ }^{3}$, Maria Cecília de Araújo Asperti 4 , Paulo Eduardo Alves da Silva ${ }^{5}$ and Susana Henriques da Costa

Escola de Direito de São Paulo da Fundação Getulio Vargas (FGV Paulo.

-211X 


\section{INTRODUCTION}

Rebecca Sandefur, professor of sociology and law at Arizona State University, is considered one of the most important references in studies on access to justice in current American socio-legal literature. Graduated from the University of Wisconsin, Madison, the birthplace of the Law and Society, Rebecca - or Becky, as she is called - received her Ph.D. from the University of Chicago, studying the social organization of legal careers. She worked for almost ten years with the Department of Sociology at Stanford University and became an associate professor at the University of Illinois at Urbana-Champaign. At the same time, she became a faculty fellow with the American Bar Foundation, where she developed a very fruitful line of investigation into access to justice, culminating with the outstanding Fellowship of the MacArthur Foundation in 2018, an award given to people with extraordinary work in different areas - from the arts and sciences to professionals in general - but rare among scholars of the theme of access to justice.

Her work stands out for her creative and keen eye that, aimed at old and poorly resolved problems of law and society, reaches unthinkable and timely solutions. As for the topic of access to justice, litigation and legal professions, it is worth mentioning the following articles she published: "Access to civil justice and race, class, and gender inequality" (2018), "Expanding the empirical study of access to justice" (2013, with Catherine Albiston), "The clinic effect" (2009, with Jeffrey Selbin), "Fulcrum point of equal access to justice: legal and nonlegal institutions of remedy" (2008), "Lawyers' pro bono service and American-style civil legal assistance" (2007), in addition to "A paradigm for social capital" (1998, with Edward Laumann), the co-authored "Urban lawyers framework: the new social structure of the bar" (with John Heinz, Robert Nelson and Edward Laumann, 2005) and the partnership in "Paths partnership to justice: a past, present and future roadmap" (2013, with Pascoe Pleasance and Nigel Balmer).

As if that were not enough, Rebecca has a contagious sense of humor, as this interview also reveals, in which she talks about her career, research and challenges related to access to justice. Good reading! 


\section{INTERVIEW}

Interviewers: Thanks, Rebecca, for taking the time to do this interview. We are very excited to hear about your career and life experience. We would like to start asking when you decided to study sociology and what was in your mind at that point?

Rebecca: I decided to study sociology when I was an undergraduate, because I was really interested in inequality, and at that time I was really interested in inequalities that emerge early in kids' lives at school. There's a line of thinking, part of it comes from Pierre Bourdieu, part of it comes from other sorts of cultural Marxist theories about class, that institutions are designed in ways that privilege some groups of people in society over others, so it's not that people have deficits, it's that the institutions are systematically built to serve some people and not others. So, what I decided, in undergraduate school, I was going to study these inequalities in early childhood and education. I found a big research project that had five faculty members and we flew around the country interviewing people, and I attached my dissertation project to this giant project and, when you have five faculty members, it's impressive that you are all speaking to each other, because on our project, they got mad at each other and the entire thing fell apart [LOL]. So I was four years into graduate school, four years into my Ph.D., and I said: "What am I going to do now?" [LOL], I don't have any data. And just by chance someone called me up and said: "I have this project on lawyers and I need a research assistant." I thought: “This is perfect," so I wrote a dissertation about how the careers of American lawyers had changed between the 50s and the 90s, using the labor market theories and stuff like that. In the course of writing that, one thing I noticed is that there's actually a lot of literature on the legal profession, and a lot of it assumes that the legal profession is intrinsically fascinating, "of course we want to know about lawyers!" To me, the main reason we want to know about lawyers was because, at least in our system, you have a public legal system, just like we have a public system of education up to college. In the public system of education, if you live in the community, you can take your kid out to school, drop him off, and the school will educate your kid. Some schools are good, some are not so good, but either way children can enroll and study - it happens. The court system is exactly the same in the sense that it's public, you've already paid for it, staffed it. But at least in the US it's become so inward-looking that you have to hire a private third-party, the legal profession, to help you use your own justice system. So I began to think about how that shapes the way problems play out, the way people understand themselves, how justice works, that kind of thing. That's how I got into access to justice.

Interviewers: And then you went to Stanford, where you were a faculty member for nine years, and your research agenda was on access to justice and inequality. How was that? 
Rebecca: When I started at Stanford, what Stanford wanted me to do was the same kind of thing I had done for my dissertation, classical contemporary sociological studies of work and professions. Once I got interested in access to justice I realized I didn't want to do what Stanford wanted me to do [LOL], so there was this period where I hadn't decided whether to do what my employer wanted or to do what I wanted. And I knew what would happen [LOL], but I would have more fun and be happier if I did what I wanted. It was a hard decision, I was very cranky for about a year and a half, because security is a very nice thing [LOL]. So, it worked out.

Interviewers: But how did inequality particularly come into your attention, as a subject of study? You've started studying inequality among little kids, then inequalities within professions. Why inequality?

Rebecca: I think for two reasons, and they're not really related. One is, I just think, intellectually, it's so fascinating that if you take three or four people and put them in a room, and they seem otherwise equal, some inequality will emerge. It's something that I don't know if it's necessary to humankind, but it's a really common part of human life. And it's incredibly resilient, so you will do some kind of reform, implement a policy to make schools cheaper, for example, and people from an educated and wealthy family will find some way to use another aspect of the institution to maintain advantage. Usually not by thinking, sometimes they think about it, but often it's just this resilient quality that inequality has. I was intrigued by that, intellectually. There are also things about inequality that I personally find very troubling. I think it's probably not always a bad thing, some of it doesn't matter, and some of it, for example in market economies, inequality provides motivation for people to do stuff, maybe that's a good thing, I don't know [LOL]. But there are lots of forms of it that are not good for human flourishing, they're not just bad for the people. At the bottom, really unequal societies have shorter life expectancy, worst health, less common public life, and that seems preventable to me in some way, and also very problematic.

Interviewers: So, it seems it took a long run until getting into the topic of access to justice. It's clear that access to justice has a lot to do with inequality, but your path began on kids, then professions and finally access to justice.

Rebecca: The short answer, when people ask me, is that it was an accident, an accident that I am doing this [LOL].

Interviewers: And what about the effects of this particular path to the way you deal with access to justice? How has the relationship between studying professions in general, legal professions and access to justice forged the way you look to access to justice? 
Rebecca: One of the things that many people who study legal profession in the US believe is that, if the profession were more diverse and reflected the society better, it would be a better profession. That may or may not be true for the following reason: we could want it to be more diverse because we think everything that is important in society should reflect society, so the education system should be diverse, the law, the police should be diverse. That's a different question than "Does it work differently once it has that composition?" Because the other thing that has happened in law, at least in the United States, is that the inequality in law itself has exploded, so now the highest paid lawyer makes 19, 25, 45 times what the lowest paid lawyer makes. That's independent of who the highest paid lawyers happen to be or where they come from, so that inequality itself pulls the profession apart and makes it more segmented than it was before. Where am I going with this? Now, I became curious about, at first, what's the inequality in law itself, how does that shape access to justice? If you want to be a legal-aid lawyer in the United States, someone who provides legal services for people for civil problems or is a public defender, with the right to counsel on the criminal side, they made, I don't know, between 25 to 45 thousand dollars, and the starting salaries in big firms in cities like Chicago, for associates, were a hundred or 150 thousand dollars, so how does that shape who is able to do those jobs? One paper I've written and talked about but never finished is looking at who is able to afford to do public-serving law. In the US, lawyers who work for the public work in small private practices, or for legal aid agencies, or for the government, corporation council for a county or whatever. You see in the US that, because people come out with 100 thousand dollars in educational loans, the only people who can afford to serve the public are people who either have inherited wealth or who have spouses with really good jobs. Otherwise, they can't sustain that debt burden and also have this relatively low-paying job. That's weird, we think it's important that communities have lawyers who reflect the communities that they serve, but what you are seeing there is the people who are serving low-income communities and communities of color are people from elite backgrounds or who married into them, which is not the dynamic we were thinking of when we wanted to diversify the profession. So that's how I started thinking about lawyers and access to justice. I started to look at, in the United States, this thing called pro bono, which is free legal services that you give to some client who can't afford them, and the client doesn't have to pay. Because that profession is so unequal now, there are two kinds of people who do pro bono: people who have to give up income to be pro bono, so some small firm, the client they serve without paying is money they don't make; and then we have this huge institutionalized big firm doing pro bono, basically law firms paying their associates to donate their time. I don't really care who is making the donation, but the dynamic that sets up is, if there's a big chunk of legal services being provided by the big firms who work for particular kinds of industries, some kinds of problems will get help and some won't. So the big firms love kids, because there's no positional conflict of interest with kids, but, if you are in Houston, with a huge energy industry, it's hard to get anybody to help you with 
any problem around energy; if you are in New York City right now, the real estate is controlled by a few conglomerates, and law firms work for one or the other of those conglomerates, it's hard to get them involved in housing law. It creates this system where the interests of the people donating their time shape what that part of the delivery system can do, and I went from there. Starting with the recognition that pro bono is not a viable solution, it's also cyclical, the whole world had this crash in 2008 and the first year, all the big firms who made these offers at a bazillion dollars to the new associates said: "Okay, we will keep you on for the first year, we have no work for you, donate your time, you can be a fellow at the blah, blah, blah, public interest place."We can't do that forever, because you are paying money for people to not work for you, which is not sustainable [LOL]. In the long haul, you saw the pro bono pull back in both the small and big firms, just when the need for legal services was increasing because people were getting laid off, having their houses foreclosed, being evicted. That was what made me think lawyers are probably not the solution to this problem, because there's no way to pay for enough of them to serve all the justice problems that people have. There's no way to donate enough of their time to do that, you have to think of something else to supplement that in the places where somebody else could do that work.

Interviewers: You mean the state?

Rebecca: You mean a functioning government? [LOL] I'd love to have a functioning government, but that wouldn't happen in my country. If you look at what's going on there, part of what makes it really hard for ordinary people to deal with courts is that courts are needlessly complicated. In the system, in the United States, if you want to make an argument about your case, you would often have to write a pleading, a little essay that explains whatever is going on. That's really hard if you don't know what you are talking about, but there are many instances where the information that needs to be in that pleading is actually really simple and totally finite. So, if you are being evicted in a city like New York, there are 16 possible defenses to eviction, so put them on a form, check all the 16 possible [LOL] instances that apply. You can codify the law in the form, you don't need somebody who has gone to 7 years of college, which is what it takes in our system, to help you do that, so that's one thing you can do, you can simplify the process itself. Another thing you can do, which is harder, is change the way judges behave. Judges, I don't know... in my country, they're like wild animals [LOL]. They're not tameable, they want to do whatever they want to do, and you can make them do continuing education and be trained, and they just won't do it because they have total autonomy, and that's part of why they do that job. There's still a little bit of scope here, that's probably not where most of the action is going to be. So you can think about other things that are not lawyers that can help people do some of the stuff they have to do around legal issues, and some of those things will be people, people who have no formal training but there's some volunteer to help them in the court house, whatever form you might 
need, or they might be more extensively trained, but they wouldn't have gone through 7 years of university, which is what takes in our system. You can also use robots and computers. Robot lawyer is mostly a joke, I cannot imagine them rolling around courthouses. But, if there are lots of discrete parts of justice problems, especially problems ordinary people have, where the law is pretty straightforward, you are just trying to figure out what the facts are and apply it, like name changes. You want to change your name? You are just supposed to be able to change your name.

Interviewers: How to translate such problems into the judiciary?

Rebecca: Lots of straightforward compartmentalized problems like that can be automated. A computer program can send a really good complaint letter to your landlord, or fill out the name change form. The challenge there is getting people to use that, so those technologies seem to work better when there's somebody there. Like when you are checking in at the airport at the little kiosks, there's always somebody there making sure no one freaks out. I think you need that in this space as well, that sort of stuff, not lawyers, that would facilitate people's problems. We should be asking what kind of things like that exist and how can we know about how good they are?

Interviewers: We read in the NY Times an interview about these navigators in housing courts, could you tell us more about that?

Rebecca:Yes, the court navigators in New York City housing courts, there were three kinds of them, and two of them seem to be really effective, and one seems like at least it wasn't hurting anything. The kind that wasn't hurting anything was a college student who was a volunteer, who had three hours of training, that person would help you find the courtroom that you're going to be in, help you organize your papers that you brought, might explain to you what the next steps are, and actually that person could accompany you as you met with the attorney, the judge. That program, courts liked it because it brought the community into the courthouse, because it was cheap - they were volunteers - and they worked much better when they were pretty closely supervised, not because they made mistakes, but because they felt more confident when there was somebody they could ask questions to. So, there was that model, then the models got more intensive. There's the form with the answers on it, the 16 possible defenses, so they have a navigator - I don't know about your courts, but, in our courts, you stand in line all the time. The Brooklyn housing courts, you wait in line, to get a number to wait in line [LOL], and a different color-coded window. Those navigators will catch you while you are in that line and say, "Are you here because you are going to be sued for not paying your rent, you have to file your answer," and they will take you through the script that will explain each of the defenses and ask you. So, they help you out. On 
average, people who they helped raised twice as many defenses as people who they didn't help, and, when we pulled case files to look at what's going on in cases, people who are assisted by those, standing in the line, helping with the answer navigators, whatever they raise as defenses, the judges are more likely to talk about it in stipulations to resolve the case. This doesn't mean that the people helped by navigators to fill out their answer won their case or that the judges agree with them. But the defenses get referenced, they become part of the conversation. And there was a third type of navigator: if those people working with you while you were standing in line thought that you were eligible to this other program, they would send you to an office around the corner for intake. This third type of navigator were social workers and they took exactly the same types of cases that, in our system, civil legal-aid lawyers would take. So, you would be income eligible, you would be poor, they try to take people who are really vulnerable, who have disabilities, language access issues, but whom you can also help, you can be eligible for stuff. The navigators would work that case the way a lawyer works the case, but they can't provide legal advice, and they can't represent you, but what they can do was go with you to each of these meetings, make sure you show up for the court appearances when you are supposed to, and outside of court they use their social worker skills to connect you to benefits and services that you are eligible for. Because landlords don't usually want you out, they want your money, and, if you can show them that this person can pay the rent going forward, then you can get an agreement so that the person can stay in the tenancy. That program was sort of super navigators; in their first year it had a $100 \%$ success rate, so nobody they served - exactly the same kind of people that traditional legal aid lawyers serve - got evicted, at the cost of about half of what a lawyer cost. The super navigators would refer cases with complex legal defenses or real legal issues out to lawyers. If you are thinking about a system that has some efficiencies, those efficiencies would include sending some kinds of cases to navigators and some to attorneys, there would be some way to figure out which cases were which.

Interviewers: Who pays for that kind of technology? Is it the government, is it the American Bar Foundation or anyone else?

Rebecca: It depends on where you are. There's an American law professor named Mary McClymont who has written a report that will be shipping on June $3^{\text {rd }}$. She tried to find all the navigator programs in the country, so one of the things she was looking at is how they pay for it. Sometimes the court gives money, sometimes, like in New York City, there was a local philanthropy, the New York Community Trust, and the other organizations - I don't think it's ever been money from the legislature so far. Sometimes the bar kicks in, the bar might give you two thousand dollars but they are never the major funder of the program, which is an important question to raise, because foundations like to seed things and move on. So, if your funding model is foundations-only, how do you make it sustainable in the long 
run? That's been a big challenge for this type of program. For the most part, the legal profession doesn't notice, because they weren't serving those people anyway, so they don't feel any pinch of competition. One of the things that I advocate for is something some states are exploring: in the US, for the most part, only lawyers can give legal advice, and legal advice is interpreted in a very expansive and vague way. If we changed the rules so that people who are not lawyers can give legal advice, you could imagine people like navigators being much more effective if they could give a bit of legal advice, and that starts to nudge into the legal profession's world.

Interviewers: Do you think there'd be a change in the scenario if you have this inequality between lawyers? It seems like the gap between them is increasing, then this share of market which doesn't interest lawyers would start to interest lawyers, perhaps?

Rebecca: I guess, what I see in the US, elite lawyers are the ones who make all the money, they couldn't care less about this kind of practice because it's never going to affect them, they don't think it's law anyway, because it's not international mergers or a patent, or whatever. The folks at the bottom of the income structure in the bar are much closer to this kind of innovations, but they're also less organized, so they're often active in local bar associations, because that's how they do business and go through their careers. But you still have to get to the state's supreme court to have a regulatory enforcement action happen and I haven't seen that happen yet.

Interviewers: You mention social workers, which is very interesting, because it's often not discussed in terms of access to justice. How do you see the interaction between social workers and lawyers, does it happen, should it happen?

Rebecca: The social workers are an example. There's a range of these kinds of co-located professional collaboration models that happen. The other thing we have a bunch of in the United States are 300 or so medical-legal partnerships. The idea is, when you come into a clinic or hospital, sometimes part of what's causing your medical problem is a legal problem. The most straightforward example would be that lots of kids in American cities have asthma, and asthma attacks are brought on by environmental toxins like cockroach feces; cockroach infestations are almost always a violation of the city housing code, so, once you figure out that is going on, the physician can refer the family to the attorney, and the attorney can tell the landlord to fix this particular problem so the kid doesn't have as many asthma attacks. There are different kinds of law like that that can be leveraged to affect health. Medical-legal partnerships have spread around the country. The social worker-lawyer collaborations exist more on the criminal side. There's this thing called holistic defense, where you have your public defender, a social worker, a benefit specialist; you might have six people 
on a team helping you around your criminal justice problems in the recognition that people with that situation usually have some bundle of problems in their lives, some are legal and some aren't. These models do create all these weird things. First of all, there's always turf battles when people with different understandings of their jobs get together, but different professions' understandings of confidentiality create these weird interactions: when the social worker or the doctor hand off the client to the lawyer, they usually want to know what happened, and the lawyer can't always tell them what happened, because it's inside the context of the lawyer-client relationship. In the same way, physicians have confidentiality obligations, the lawyer wants to know what happened and the doctor can't tell them. That dynamic can make those situations delicate, because people are trying to work together, but then they can't - "Why can't you just tell me what happened?" [LOL]

Interviewers: Could you tell us a bit more about comparative studies in terms of access to justice? What are the challenges in researching this area?

Rebecca: There are two big challenges. One is there's very little data. For example, in the context where I live, probably $97 \%$ of court cases are in state courts, but the only decent data that we have is on federal courts, where $2 \%$ of cases are, and that's different in a lot of countries, so the thing you want to know about, you can't compare, because there's no information. But then the other thing, when we first started this access to justice stuff, I was still thinking very much about lawyers, and I thought: "I am going to find data that will let me look at how legal professions are organized and how that shapes access to justice, wouldn't that be cool?" While there are a lot of things that are also different [LOL], in the legal context, so thinking about what can be comparable and what just can't be, you can't possibly create enough variables to net out all the variation that you are not interested in. The way I started to think about it is: "What are the big similarities we can learn from one jurisdiction to another?" The one that comes to mind is, I used a lot of research from Australia because there are important similarities: both their country and my country are gigantic spaces, with lots of rural areas with impoverished, indigenous populations. So, there are a lot of similar problems. Things they've figured out work in Australia, we can try in the United States. So thinking about what are the dimensions that will lead us to recognize lessons that can translate from one country to another, dimensions about context, about particular types of problem... Domestic violence happens everywhere, for example, countries around the world face similar challenges in dealing with that social problem, so, if you can find something that works in Brazil, it probably would work in the United States, South Africa and many other places. The differences you would run into are figuring out how to implement it in those different places, because that becomes who the stakeholders are, they have to be on board, and what it takes to convince them, I think it's very different. 
Interviewers: We can see that your work on access to justice is really based on what you call a "bottom-up perspective." In Brazil, on the contrary, we are used to think about access to justice almost exclusively from a "top-down perspective," trying to reform statutes, change institutions, etc. On one side, it's a bit more comfortable for us to compare with other systems, but, on the other side, we are both still facing problems of ineffectiveness. Related to this, it's helpful to pick up the expectation of the judiciary output from these experiences in the judiciary by ordinary people.

Rebecca: I think there are people who do studies of public trust and confidence in the judiciary.

Interviewers: The expectations are so different from the lawyers, from the students, for example, and from ordinary people watching a judge decide their own conflict.

Rebecca: I am not sure this answers the question, so push back if it doesn't. I don't know if the procedural justice literature has infiltrated here yet. In the United States, courts love procedural justice, they will invest in judges to get them to behave in fair and impartial ways and to communicate clearly, because courts perceive that it increases their legitimacy, and the degree of community support they have. But it's not because judges have developed a deep understanding of what it's like to be a litigant, and what I think about this, in every country I've ever talked with, the judiciary and the bar are so conservative. We have debates on how to change that, to change the legal education - for example, should it have more experiential components, should we teach people about the social aspects of legal problems, or is the way to do it to boss judges around in different ways? But I don't know if anyone has come up with, I haven't seen a solution to that problem. I have seen individual judges who are amazing examples of how to do it well.

Interviewers: We would like to go back to the top-down vs. bottom-up perspectives of studying access to justice. How did it come up to you? Was it a comparison with civil-law systems with a top-down perspective?

Rebecca: The way I started to think about that, conceptually, was to say... Because, once you start thinking about ordinary people's experiences, you see that very few make it to formal legal institutions, so, in a society like mine, they get resolved at church, they get resolved by having your family help you out, or you resolve them on your own. If you're in a different society with traditional legal structures that are parallel to the court system, then you might go there. So, if very little of this activity makes it to the justice system, nonetheless it's getting resolved, or at least it's over. If you go back to the rule of law, the question you would have is, whoever resolved it - whether it was the chief of the community 
or your pastor or whoever -, was it resolved in some way that sits inside the norms that we set for that kind of problem? Because it seems to me that we make laws, originally, because we say to ourselves: "There are some activities that are so important, if you are in a democracy, that you have a collective stake in how that goes down." If you are a landlord, you cannot take all of your tenant's stuff and throw it on the front yard and change the locks. You have to go through a process if you want to remove the tenant. If you want to take somebody's kids away, you can't just go and get them, you have to go through some kind of process. You have access to justice, in my thinking, as long as whatever happens, whoever does it falls within the bounds of what the rules would say should have happened. Now, you might well be thinking: "Wow, what a huge measurement problem" - how can we know if a problem was resolved within the bounds of the law or not? Which it is, but there are some things where accuracy is pretty easy to determine; name changes are my favorite example. You either changed your name or you didn't change your name, the court is supposed to accept the form if you fill it out. They either do it or they don't. Once things get more complicated, accuracy is harder to measure. The thing we need to start to look at is disparity. For example, whatever is happening, it shouldn't be that African Americans are 25\% more likely to get evicted than white people if all of them are poor. You start to see that as a way of assessing things. The only way I have tried to operationalize a comparative analysis in this context is in a paper called "The fulcrum point of equal access to justice: legal and nonlegal institutions of remedy." The idea was that, if most people's problems are not making it to the justice system, it means that the justice system is one piece of a whole set of institutions of remedy for justice problems, so what do those look like in different societies? Let's pick two that are quite similar, the UK and the US, that happen to have data that allow us to compare them. In the US, if you have a justice problem, you have two choices: you can hire a lawyer or do something else that won't involve the law, because lawyers have a huge monopoly on providing legal services. In the United Kingdom, anybody can give you legal advice, so there's an enormous advice sector that has been around for 65 or 70 years that is very well trusted, including the Citizens' Advice Bureau. In the US, if you have a problem with something in the regulated industry, like your phone or your bank, those problems are usually important to you, but they're much smaller than whatever it costs to file a lawsuit. If you get into a fight with your cellphone provider over 75 dollars, it will cost 750 dollars to pursue the case. You can write the regulator in the US and say, "This company is being very bad," and the regulator will say, “Thanks for letting us know” [LOL]. But, in the United Kingdom, there's an ombudsman system for most major regulated industries, and it's a government office that is independent of the industry, and you file your complaint over 75 dollars with them, they investigate it, they make a binding determination and the problem is over, you either get the 75 dollars or you don't. The choices that you have in those two contexts for solving the same type of problem are different because the institutions are designed differently. So, what I looked at was how does this shape social class differences in the way people solve 
their problems? Because the other thing that happens in the UK especially, back when I was looking at this, $60 \%$ of the population was eligible for some kind of subsidy to buy legal services on the private market, because they had that very expensive judicare system. So, you compare how Brits with certain kinds of problem handle them to how Americans with certain kinds of problem handle them, and you compare the two societies, and you see that, because in the United States you have a choice between law and nothing, poor people are much more likely to do nothing. And in the UK you have a choice between law, ombudsmen, advisers, and law was also for many people free, and, even when law is free, people in the United Kingdom would rather go to those other sources of remedy. You see much smaller inequalities doing anything about problems, because there are so many things you can choose to do. We have to start to think about how we would design a set or institutional structure around the problem in a way that reduces the difference in people's access to resolution, even if they might go through different doors to get there.

Interviewers: So, it's not just about a one-way top-down or bottom-up perspective, but a combined cycle of both. People's choices are based on many options, and such options are designed based on people's experiences and expectations.

Rebecca: I think that's true. For me, the touchstone is always the public experience with the public institution, so it has to work for them. And it's interesting, when I talk to American audiences about this, when I talk about technological solutions that can do a legal act, some of them say: "Don't you feel bad that you are driving lawyers out of business?" And I have to stop myself and say: "I am not in charge of lawyers, lawyers are not my priority actor here" [LOL], my priority actor is the public and access to justice. There will have to be changes in the way you do things to produce that outcome, and maybe that means some lawyers will do something else.

Interviewers: We have talked a lot in Brazil about access to justice because we were very influenced by the Project Florence report, from Cappelletti and Garth. The report was written in another time and space, compared to Brazil. However, one of the project's main idea was that, to have rights, you have to have access to justice. In a European welfare state context, people dreamed about having all social rights guaranteed. In the US, if we are right, the access to justice ideal emerged in a scenario in which people believed in the potential of courts to change society. We think that this scenario changed a lot in the US. Galanter argued in a paper from 2010 that you cannot give access to justice to everybody, that you have to make choices about it, because in society the social capability is expanding. Therefore, you will always need more and more access to justice. How does "access to justice" fit in this current scenario? 
Rebecca: I think you are right... The way I think about it is, when Cappelletti and Garth were writing that gigantic study with all their collaborators, there was still a lot of optimism in the US with the war on poverty and in Europe about these great welfare states, that we are going to create this kind of common life for everybody and it's going to be really good. And they thought that could see the unfolding of inevitable stages of history, and they thought that we were going through the third and best at the time. It didn't quite work out that way, but I think that analysis was a product of that moment when we thought law was going to be central to resolve a lot of that stuff. What you can see in the US and in a lot of countries in the world, access to justice is a medium-term anti-poverty tool, it's maybe a tool for encouraging the participation of groups that are marginalized in the main institutions of their society. It's maybe a tool for taming the bad behavior of certain bad actors if you can organize them systematically, but not the thing that will solve all the problems - which was what it was thought to be until 20 or 15 years ago. The other thing that you see that is interesting, one of the criticisms to access to justice is that it's individual and a Band-Aid. So, we are going to make sure you don't get evicted, but, the fact that housing is really expensive and people get evicted all the time, they're unaffected by us solving your individual problem. It doesn't have to be that way but it's usually the way access to justice is implemented. There's another strand around the same kind of activity that goes under the brand of legal empowerment, and it comes out of development, the idea of legal empowerment, and because it comes out of development it's in speeches by Madeleine Albright, the former secretary of state in the United States. The idea is, whatever you do when you provide legal empowerment, it actually changes the capacities of the people and communities you are working with, so they become more able to recognize, identify, think about, and act on those problems and maybe become more able to organize the feedback to the system. But nobody thinks this will fix anything in the totalizing way folks believed 40 years ago. It's supposed to be a development strategy because with legal empowerment you have contracts, markets, you can sell stuff or whatever, and have predictable economic relationships. But I think another part of the attraction of the idea of legal empowerment, at this moment in history, if you watch democracy getting dialed back in every major country in the world, this is the way to try from the bottom-up again to get democracy to be reinvigorated.

Interviewers: Does it seem that, when you're empowering someone, you're actually going top-down? How do you think empowerment works, that comes from the community?

Rebecca: Anytime you come from the outside and give someone something, there's always the possibility of paternalism. When I've seen it in its least paternalistic forms, it's either programs where you come in and you work with the community. There's an organization called the Namati that is a collective of paralegal programs around the world, and what most of them do, most of them are created locally, by local activists who say, "Hey, we are in rural India and 
the only asset we have is our little piece of farm land and we want to make sure this bad energy company and my mean uncle can't take it away, so we need a title to the land, but none of us can read, the courthouse is far away, and the rats have eaten all the documents." So you train them, that community, to help their neighbors with that specific problem so they can retain that asset that they have, and that seems less paternalistic to me. The analogue I see in the United States is community-led design. We have these people, they're much more from the outside than those paralegal models, we have these people who say: "The world is messed up and I want to devote my life to fixing it, what am I going to do?" So, they will become social entrepreneurs, funded by foundations, and, when they do community-led design, they take on issues that communities themselves decide are the problems they want to work on. In New York City there's a group called Just Fix - I will talk about it later this week - that writes complaint letters about housing conditions in your apartment. When the people who founded Just Fix knew they were going to work on housing issues, they knew they weren't experts in the housing conditions of the communities they wanted to assist, so they started out by hanging out in courthouses, watching what people did, what kind of barriers they ran into and then going to community groups and tenants unions, and asking them to have meetings with people who were members, to talk about what it is - if you wanted something that you could do better, what would it be? And they worked with the same communities to design the tool that writes the complaint letter, so that's another way. Then the question is the tool or the experience legally empowering. The empirical question I would have is, after I joined the tenant's union, made the complaint about my landlord, am I different going forward? Is my building different going forward, are we more aware of our problems, do we talk about them more, do we try to do things about them more, and then the next time I encounter another problem do I handle it differently than I would if I had not had this experience? I don't think we know the answer to that question.

Interviewers: Now it's possible to have a new global research on access to justice. Do you think that the starting point should be the same agenda of the Florence Project?

Rebecca: I'd love to see Bryant and whoever he's working with make a global comparative study. I think, rather than thinking about common methods, wouldn't it be cool if at the beginning they could agree on the questions they're going to ask about every place? And then you could discover answers based on resources you have, the place you're in, and that sort of thing. I think that would be great.

Interviewers: We would like to shift a little bit the subject to ask you about the paper you've wrote about "social capital."

Rebecca: I remember it vaguely [LOL]. 
Interviewers: Brazil is a deeply unequal country, where the law is an arena for a few people who can operate in it. In this scenario, people who have access to justice are those who have some kind of "social capital" - if we understood the way you work the concept. Elites control the legal system in several ways: lawyers who want to be the exclusive gatekeepers of courts, judges who want to receive even more power. In the end of the day, access to justice is not just an issue of empowering ordinary people, since the system itself is based on exclusive access to some people and not others. In the 80s in Brazil, we had a big discussion about the implementation of Small Claims Courts. The general goal was to give access to justice to conflicts that were outside courts, the less affordable and cheaper ones. However, a huge resistance argument was that Small Claims Courts would be considered a secondclass justice for the poor. Regular courts would remain available for the repeat players and for rich people. How do you see that when the current alternative is still guaranteeing the courts' door to people who have money and is still designing other ways to solve the conflicts of the poor? These other doors, are they going to be a second-class justice?

Rebecca: The way I think about it, you want to expand access to justice, so people go back to this idea that it's not necessarily just law, but it's whatever the solution is, it's "lawful," it resolves within the norms institutionalized in the law. We want to expand that so that more people and more problems get that treatment. We also want to equalize it. As part of expanding and equalizing access to lawful resolution, some problems that people have now that go to court will go somewhere else, and some issues of the less-resourced people that don't make it into the courts will start making into the courts, because you want things to make it into the courts for two reasons. One is that's the way the legal system works, it doesn't have any knowledge of stuff that doesn't come in front of it, and that's how you get enforcement activities that are bigger than the one person with the original problem.

Interviewers: You have mentioned many papers you have written; do you have a favorite one?

Rebecca: I think my current favorite is that paper looking at whether it's procedural knowledge, or substantive legal knowledge, or relational knowledge that makes lawyers have a better advantage on their cases, because that paper was really hard [LOL].

Interviewers: You mean hard to conceive or to write it down?

Rebecca: There were two parts of it that were hard. One was - I don't know if you have this experience - not all papers are like this, but sometimes you're going along, and you're like, "I got it, that's the way to think about this," so there, it took a while to get to the way to think about it. The other part that was hard was methodologically. I had to learn a whole new 
crazy, arcane, nonparametric thing, that there's no computer program to do, so I did it in Excel, by myself, and, when I was done, I knew how to do this crazy thing [LOL].

Interviewers: And what about other legal scholars' work, do you have a favorite that you are currently dialoguing with?

Rebecca: There's a fellow named John Gaventa who wrote a book called Power and powerlessness. I don't know if you know Steven Lukes' theory of the three faces of power - he claims he's a sociologist, but he speaks more like a political scientist. There's straight up coercive power, then there's agenda-setting power, and then there's power that is so powerful that it shapes what you want, so that you actually misperceive your own best interests. Gaventa was a student of Lukes and he wanted to understand what he called "quiescence", which means just being totally still and inactive in the face of problems that you recognize as problems. He looked at coal miners in Appalachia, and he was like "Why?", and miners can tell you that these companies are screwing us over, this is very unfair, and they don't do anything about it, they don't complain - how do you understand that? There's an illustration of that third face of power. This was a very profound book for me. Another one that I found really helpful was by John Conley and William O'Barr. Conley is a law professor, and O'Barr is a legal anthropologist; they've done studies on small claims courts, they watched how people make claims. The way they analyzed, some people come in, and they tell these long stories about "how someone hurt their feelings, this person is mean, this is unfair." By contrast, other people come into court and say, "This is what I want, I want 500 dollars because this and this happened." This second group of people who come in with this deductive search for claim are much more successful in court than the people who tell long stories about what's happening to them. In their research, they just identify these as two different styles, one that's more successful in court than the other. But, if you look at social class, in the United States, the two styles are associated with different groups in the population, and this starts to explain why you would see the inequalities in how people's court cases turn out. Courts get frustrated with people who come in and tell stories, they're thinking: "Would you please stop telling me your long story?", even though that long story offers the court the same facts as the short one.

Interviewers: Looking at your biography, we have discovered that you are a member of an indigenous nation. How did that happen?

Rebecca: Yes, I was born in Oklahoma. In Oklahoma, many people who live there claim some kind of American Indian ancestry, and the reason for this is that the rates of intermarriage between whites and American Indians are very high. Oklahoma in the $19^{\text {th }}$ century was where many American Indians were forcibly resettled after the expanding US took their land. 
There was a big removal in the first half of the $19^{\text {th }}$ century called the Trail of Tears, because so many people died, and in that removal a whole bunch of people, including my great grandmother's parents, were forced to walk from the eastern United States to Oklahoma, which at that time was called “Indian Territory." Later, Indian Territory was opened to white settlement. And eventually many Indians who were in what became Oklahoma married white people who were later settlers, and that's what maked me.

Interviewers: What are the projects and plans you have related to the MacArthur scholarship?

Rebecca: The way I've been thinking about it is: one thing that we think we know, if we are going to solve some problem, if we are going to work on some problem like eviction or debt collection, the effective way to work on that problem wouldn't be implementing just one program, or changing just one rule. There would be a set of things that people do simultaneously, multiple, integrated reforms, not just in law but also in other sectors like social services, human services, education. So what I am trying to do is find jurisdictions where people are thinking that way about some specific problems, and study two things. One is how to pull it off, because it's not easy or self-evident, and the other is, we think this is what we are supposed to be doing, but does it do what we think it's going to do, is it effective?

Interviewers: What kind of projects are you planning for the next years? Do you foresee a change on your main subject of research?

Rebecca: I don't think so, I'm finishing a project on legal technologies, and next year I'm on sabbatical and I want to write a book on civil justice and inequality in the United States, about the way civil justice takes inequalities and magnifies them, and what kinds of solution are already developing that can mitigate that. Hopefully, while I'm working on that book I will be able to find some jurisdictions that are doing this combined model for tackling this problem and start to set up those research projects for the next few years.

Interviewers: So, it will be something related to access to justice and technology. Is it possible to ask the judiciary to decrease social inequality? In a society like the Brazilian society, where we have huge social and economic inequalities, do you think that it is the task of the judiciary to decrease social inequality?

Rebecca: Not just in law?

Interviewers: Yes. For example, what we see here in Brazil about the judicialization of politics is that the judiciary doesn't work to decrease social inequality, but increases it because a huge part of society does not have access to justice and because judicial decisions do not 
affect social inequality. They usually say: "This is not my problem, this is a social problem, not a legal problem." I think you work with an idea of "inequalities related to law," which seems an assumption that it's also a legal problem.

Rebecca: In the US, the way that happens is if some... I don't know how the structure of your supervision of judges is, but sometimes there will be some judge, presiding judge or chief judge who really believes that we're supposed to have equal access under the law, and really thinks some problems with inequality are bad. So that person can be very effective in showing leadership and changing the way the court system works. One of the marquee examples would be New York State. When Jonathan Lippman was the chief judge, he made access to justice his issue. He did a range of things. One was he thought about what rules that would keep some cases out of court. For example, in the US, I think a third of Americans have a debt in collection. Those debts don't all become lawsuits, but what happens is, let's say, you're my credit card creditor, and I won't pay my bill for a while. You will call me a few times and, when I don't pay you, you will decide this is a big waste of your time and you will sell my debt to a collection agency. The collection agency will bother me, and then after a time the collection agency will sell the debt to what's called a debt buyer, and he might sell to the next debt buyer, and so on. Those sales of debt are at a highly discounted rate - for every thousand dollars I owe, for example, a debt buyer might pay 10. Debt buyers essentially are making a wager that across their portfolio of debts they will be able to recover enough to make a profit. By the time the debt is sold 3 or 4 times, I might have paid part of it off, but the person who now owns the debt doesn't know I paid money to the original creditor. I may not remember that I paid part of it off. The debt is often sold without the paperwork that shows that the debt is owed by someone who is actually me and not some other Rebecca Sandefur, with a different middle initial or a different birthdate. The paperwork will not exist that verifies that I owe the precise amount the debt buyer is suing me for. This problem sometimes goes under the name "bad paper" - the debt buyer does not have adequate documentation to show that I owe the debt. So the State of New York under Judge Lippman said: "You cannot file one of these lawsuits in this state unless you attest that you have documentation to show that this is the precise amount of the debt and this is the actual person who owes it." This was a huge change because a whole bunch of people are facing specious claims for debt they don't owe, many of them would default - either because they're afraid, or they don't have the money, or they don't understand they have to show up in court - and they'd end up with debt judgments against them that affect their credit ratings, they can go to jail under certain circumstances, so it has a big impact on a whole bunch of people. But a very small thing, just one rule, the "lowhanging fruit," as we say in the US, increased access to justice for thousands and thousands of people. 
Interviewers: Your research is mainly about individual conflicts. Here in Brazil, we developed a class action system, very much inspired by the American one. Do you think that class actions and group litigation are an alternative for access to justice?

Rebecca: I think it can be. The examples in the US that have been successful would be different kinds of environmental disasters, asbestos... Brown v. Board of Education, a case that declared that students could not be separated on the basis of race in schools. That was a huge class action that affected a huge number of people. But, to go back to the point of inequality having an amazing staying power, schools in America are actually worse now than they were when that decision came down. But the decision did change people's thinking of what's appropriate. It shaped people's views about education and diversity. So those big cases can change the normative discourse, even when they don't actually fix the problem that motivated the case. To go back to the question, I think class action cases certainly can be impactful, but less in terms of remedy for the people harmed. The benefit is more, probably, that the big bad actor, the mean company, the corrupt agency, the organizations engaging in the racist practice, these bad actors are brought into compliance with the law, and hopefully the other potentially bad actors that are thinking about engaging in those practices would be a little more reluctant to do so. But at least in the US the individual remedies are very small. For example, I've been in the class of plaintiffs for a number of these things. You get a letter from a law firm: "You've been a client of this credit card" or "You bought this car," or whatever, and you can opt out and declassify your lawsuit or you can be part of a lawsuit. So you say to yourself: "Sure, I will be part of a lawsuit." A few years later, because it's very slow in our system, almost all that is settled - very little of this activity is litigated to some kind of formal judgement. This also raises issues about, if something is litigated, there's a public record; whereas if something is settled, what was agreed to and what was attested is not necessarily public record. Then, as an individual, you get a tiny monetary payment - I once got a check for one dollar and 25 cents as a member of the class remedy for an injury of much larger monetary size - because the courts and lawyers take a big chunk of it. The size of the award is usually much smaller than the monetary injury that was experienced. So, the impact of class actions is probably bigger at the systemic level than it is in terms of making whole individual people who have been wronged.

Interviewers: Law and Society as a movement is around 50 years old. Now we can see they're trying to involve young scholars into the association and we guess you were one of those...

Rebecca: ... not so young anymore [LOL].

Interviewers: A younger reference, if we can say that. How do you see the influence of social legal studies in the United States? We guess that, when the Law and Society movement 
was created, social legal scholars were an influential voice. Is this the same nowadays in the US?

Rebecca: You mean in the academy?

Interviewers: Outside the legal academy.

Rebecca: In the US, right now, academics don't have a lot of influence on anything. I do think one thing is happening in the United States, it's that that movement has been so successful in some ways that it split [LOL]. So now you have the law and society crowd, which is sociologists, political scientists, a few economists, some law professors, some psychologists, some anthropologists. It's very cross-disciplinary, but there's some kind of theory going on, there's this idea that, even though there's all these different disciplines, there's some canon of thought that we are participating in. But split off from that is empirical legal studies, which is mostly economics departments at law schools, and explicitly they can have a theory if they want to, but they often write papers where they just count things and tell you what they found. I think that's a sign of success in empirical research in law, in the US, that you can actually have two schools of it, the school that's more theoretical and the school that's straight-up empirical.

Interviewers: Would you think the Law and Society Association would be truly open for more international agenda and participation? Would there be a more international leadership?

Rebecca: I think it's definitely going that way. I am right now the editor of Law \& Society Review, and I would bet you 50 American dollars that the next editor will be someone who does not work in the United States, and I think that would be a good move. Speaking of editorial side, the association definitely wants to keep opening up to the world. The norms of academic scholarship are so different in different parts of the world, and LSR is an Americanstyle peer review journal. One of the things I've been thinking about is what would be the explicit things we can tell people in advance about what to expect from American-style peer review. So that, if they're coming from a different set of conventions, they would be successful at LSR. Because I think there's all kinds of interesting work going on around the world but expressed through different conventions. You can't get your work into law reviews unless you meet law review conventions, and you can't get your work through peer review unless you know and enact the peer review conventions. We need to find ways to communicate those conventions - that's another part of opening stuff up, I think.

Interviewers: Any tips for new researchers to continue to organize this agenda? 
Rebecca: To people, young researchers who are interested in studying access to justice, the main tip I would give you is: don't believe anything anyone tells you unless you have some empirical basis for it. That's one of the most surprising things in my time working on this, the number of things we just believe that turn out not to be quite true, and that's an amazing opportunity to make contributions, publications - and it's also much more interesting. And for minority groups entering into academia and into this area of research, different countries have different conditions; your academic system where you are, different countries have different ways of facilitating diversity, of challenging it. I think one of the most important things that you can do as an outsider coming into a new place is make connections with the people who are established, because they can help you move through this process. You have every right to be here, and every right to ask for what you need. We hope that institutions will create ways for that to happen (for example, in the United States we had affirmative action and formal mentoring programs) but institutions are not always very good at doing that effectively. For those of us who are already here in the academy and doing this work, we have to realize that students are not all the same. Some very talented people who can spark the world will not be pushy, won't ask us for help, won't feel comfortable telling us what they need. It's our responsibility to work to support their success. The charter of my university says the institution's success is "measured not by whom we exclude, but by whom we include and how they succeed." I think that's the right goal.

\section{ACKNOWLEDGMENTS}

The interviewers would like to thank the University of São Paulo Law School, that have financed professor Rebecca Sandefur's visiting to Brazil. This interview was an interinstitutional initiative of São Paulo Law School of Fundação Getulio Vargas (FGV DIREITO SP) and University of São Paulo Law School (São Paulo and Ribeirão Preto).

\section{REFERENCES}

ALBISTON, C. R.; SANDEFUR, R. L. Expanding the empirical study of access to justice. Winsconsin Law Review, v. 2013, n. 1, p. 101-120, 2013. 
FONTAINHA, F. de C.; NUÑEZ, I. S.; ALVES DA SILVA, P. E. Entre o direito e a sociedade: entrevista com Bryant Garth. Revista de Estudos Empíricos em Direito, v. 3, n. 2, 2016.

GALANTER, M. et al. Talking about the limits of legal change: an interview with Marc Galanter. Revista de Estudos Empíricos em Direito, v. 1, n. 2, p. 200-211, 2014.

HEINZ, J. P. et al. Urban lawyers: the new social structure of the bar. Chicago: The University of Chicago Press, 2005.

SANDEFUR, R. L. Lawyers pro bono service and american-style civil legal assistance. Law and Society Review, v. 41, n. 1, p. 79-112, 2007.

SANDEFUR, R. L. Acess to civil justice and race, class and gender inequality. Annual Review of Sociology, v. 34, p. 339-358, 2008.

SANDEFUR, R. L. Fulcrum point of equal access to justice: legal and nonlegal institutions of remedy. Loyola of Los Angeles Law Review, v. 42, n. 4, p. 949-978, 2009.

SANDEFUR, R. L.; LAUMANN, E. O. A paradigm for social capital. Rationality and Society, v. 10, n. 4, p. 481-501, 1998.

\section{HOW TO QUOTE THIS INTERVIEW:}

SANDEFUR, Rebecca; GABBAY, Daniela Monteiro; CUNHA, Luciana Gross; ASPERTI, Maria Cecília de Araújo; SILVA, Paulo Eduardo Alves da; COSTA, Susana Henriques da. Access to justice and inequalities: an interview with Professor Rebecca Sandefur. Revista Direito GV, v. 16, n. 2, maio/ago. 2020, e1967. doi: http://dx.doi.org/10.1590/ 2317-6172201967.
Rebecca Sandefur

American sociologist Who WOn a MacArthur "Genius" FELLOWSHIP IN 2018 FOR “PROMOTING A NEW, EVIDENCE-BASED APPROACH TO INCREASING ACCESS TO CIVIL JUSTICE FOR LOWInCOME COMMUNitIES". PROFESSOR IN THE SCHOOL OF SOCIAL

and Family Dynamics at Arizona State University and Faculty Fellow at the American Bar Foundation, Where she FOUNDED AND LEADS THE ACCESS TO JUSTICE RESEARCH INITIATIVE.

HER RESEARCH INVESTIGATES ACCESS TO CIVIL JUSTICE FROM EVERY ANGLE - FROM HOW LEGAL SERVICES ARE DELIVERED AND CONSUMED, TO HOW CIVIL LEGAL AID IS ORGANIZED AROUND THE NATION, TO THE ROLE OF PRO BONO, TO THE RELATIVE EFFICACY OF LAWYERS, NONLAWYERS AND DIGITAL TOOLS AS ADVISERS AND REPRESENTATIVES, TO HOW ORDINARY PEOPLE THINK ABOUT THEIR JUSTICE PROBLEMS AND TRY TO RESOLVE THEM. SHE EARNED HER B.A. FROM THE UNIVERSITY OF WISCONSIN. IN 2001 SHE EARNED HeR Ph.D. FROM THE University OF CHICAGO WITH A DISSERTATION ON "THE SOCIAL ORGANIZATION OF LEGAL CAREERS". SHE SERVED PREVIOUSLY ON THE SOCIOLOGY AND LAW FACULTIES OF STANFORD UNIVERSITY AND THE UNIVERSITY OF ILLINOIS AT Urbana-Champaign. In 2013, Sandefur was The Hague 
Visiting Chair In the RULE of LAW. In 2015, She WAS NAMEd Champion of Justice by the National Center for Access to JUSTICE. In 2018, SHE WAS NAMEd A MACARTHUR FELLOW FOR HER WORK ON INEQUALITY AND ACCESS TO JUSTICE. SHE IS CURRENTLY EDITOR OF LAW \& SOCIETY REVIEW.

Rebecca.Sandefuraasu.edu

\section{Daniela Monteiro Gabbay}

Professor at São Paulo Law School of Fundação Getulio Vargas (FGV DIREITO SP). Ph.D. and MASTER OF LAWS IN Civil Procedure from the University of São Paulo. She was A VISITING FELLOW AND SCHOLAR AT YALE UNIVERSITY IN 2008 ANd AT THE LONDON SCHOOL OF ECONOMICS AND POLITICAL SCIENCE (LSE) IN 2013. daniela.gabbaylafgv.br

\section{Luciana Gross Cunha}

Professor at São Paulo Law School of Fundação Getulio Vargas (FGV DIREITO SP). Ph.D. ANd M.A. IN POLITICAL Science from the University of São Paulo.

Luciana.Cunhalafgv.br

\section{Maria Cecília de Araújo Asperti}

Professor at São Paulo Law School of Fundação Getulio VARgas (FGV DIREITO SP). Ph.D ANd MASTER OF LAWS IN

Civil Procedure from the University of São Paulo. She was A VISITING FELLOW AND SCHOLAR AT YALE UNIVERSITY (FoX INTERnATIONAL FELLOWSHIPS, 2011-2012). ResEARChER AT Centre for the Study of Human Rights and Companies (FGV DIREITO SPI.

Maria.Aspertilafgv.br

\section{Paulo Eduardo Alves da Silva}

Associate Professor at the University of São Paulo (Law School of Ribeirão Preto). Master, Doctor and Lecturer in LaW From the University of São PaUlo. He has beEn a VISITING SCHOLAR AT THE CENTER FOR the Study OF LAW AND Society (UNIVERSITY OF CALIFORNIA, BERKELEY, 2016) AND AT THE INSTITUTE FOR GLOBAL LEGAL STUDIES (UNIVERSITY OF WISCONSIN, MADISON, 2012), AND A VISITING RESEARCHER AT

the Institute of Applied Economic Research (IPEA, 2009/2011 AND 2019/2020). FOUNDING MEMBER OF THE Network of Empirical Studies in LaW (REED).

pauloeduardoalveslausp.br 


\section{Susana Henriques da Costa}

Professor of Civil Procedural Law at University of São Paulo. Professor at GVlaw at São Paulo Law School of Fundação Getulio Vargas (FGV DiReito SP). Ph.D. and

Master at University of São Paulo. She has been a VISITING SCHOLAR AT MADISON LAW SCHOOL (UNIVERSITY OF Wisconsin) and at the Università di Firenze. State Prosecutor of São Paulo. suscostalausp.br 